Julia Sorvina, a teacher of tourism organization

Kyiv National

University of Trade and Economics College of Commerce and Economics 2/4, Lvivska str., Kyiv,02000,Ukraine

ORCID: 0000-0001-8714-4039

\author{
Anastasia Semenets, \\ Student of Kyiv National \\ University of Trade and Economics \\ College of Commerce and Economics \\ 2/4, Lvivskastr., Kyiv, 02000, Ukraine \\ ORCID: 0000-0002-5552-208X
}

\title{
EXCURSION ACTIVIES OF THE XXI CENTURY. THE PROBLEM OF EXCURSIONS
}

The article considers the concept of impression economy as an integral part of the service industry and its practical components. Feelings have become an integral part of marketing, management, service activities, future development of companies. This article discusses issues regarding the context of emotions, experience and impressions in tourism, excursion service, the issues of excursions in the XXI century.

Keywords: excursion, theexcursionactivity.

Relevance of research topic. At the moment in the service economy, that is, many companies, the goal is not just to implement a package of services, but to implement the experience. Experience is a separate economic proposition that is different from services, just as service is different from goods. Experience is not just an amorphous structure; it is as real proposition as a product or service. Companies are looking for the ways to create an attractive buyer experience for which they will receive a good reward.

The main problem and the advantage is that not all established companies are ready to move from simply selling services to selling experience, as in the past economic shift - from industry to service economics, and ingeneral, not all are fully familiar with the concept of «economics impressions». However, companies have to move to a new level of economic value of their offers, otherwise they will have to deal with the commercialization of their own business [1]. 
Excursion activity is an integral part of tourist activity, therefore, in case of a problem, tourism cannot fully exist. Now this tourism industry needs modernization to satisfy the modern tourist.

Formulation of the problem. The purpose of the article is to study the process of formation and organization of excursion activities in the XXI century. Defining the prospects and developing recommendations on the range of excursion obedience, improving the efficiency of the excursion activity organization, taking into account the requirements of significant activation of innovation as a motivator for the development of economic relations.

Analysis of recent researches and publications. In 2017, at one of the webhosting sites, there was a survey of people aged 15-50 years, about tourism by the sea, where the question of excursions was raised. [2] Here are the results:

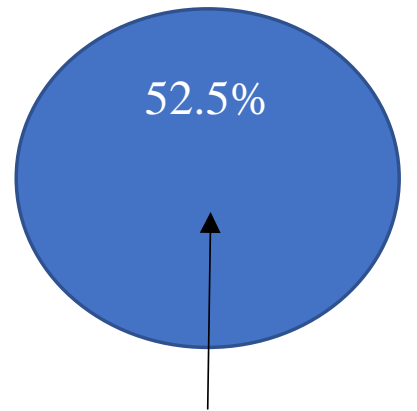

From 31-50

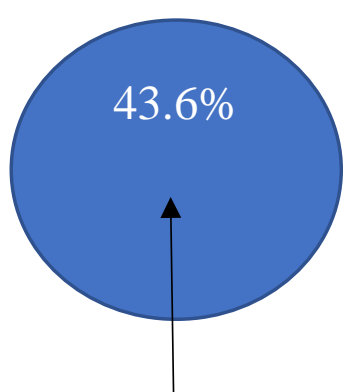

From 21-30

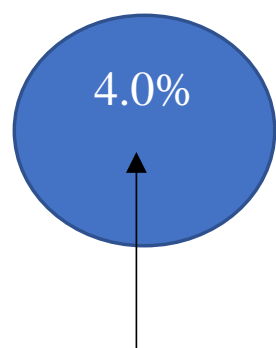

From 15-20

Figure 1.1 Age of respondents, (\%)

Source: Tourism by the sea: Statistics of the choice of respondents 2017-2017
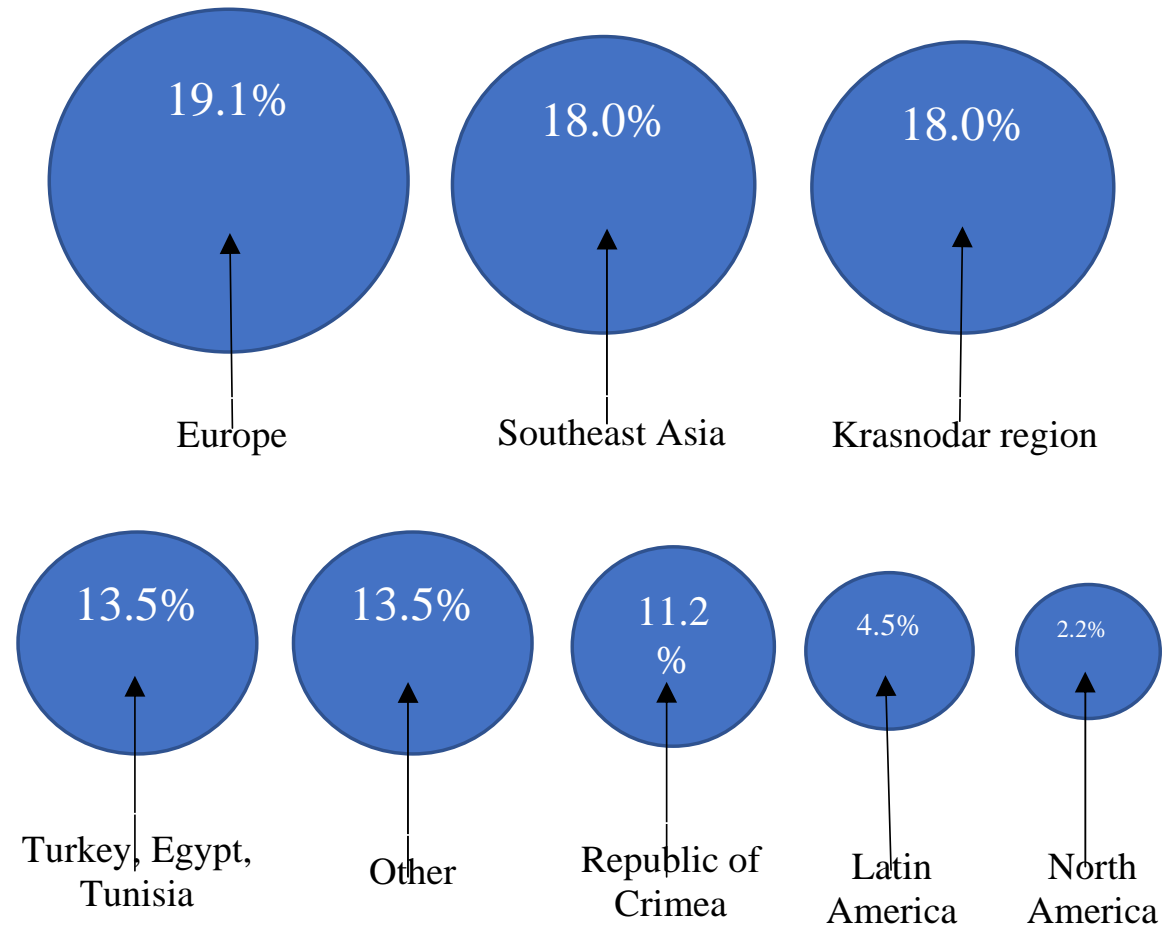

Figure 1.2. Geography, (\%)

Source: Tourism by the sea: Statistics of the choice of respondents 2017-2017 


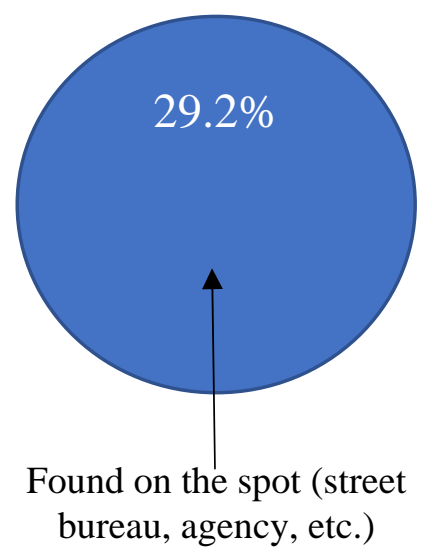

bureau, agency, etc.)

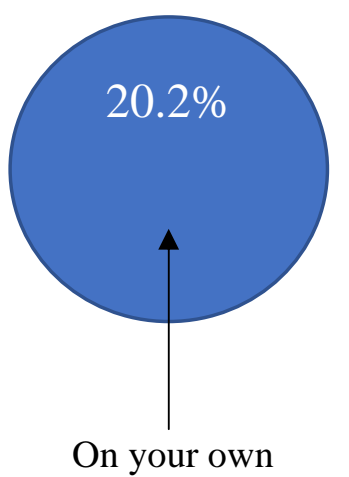

On your own

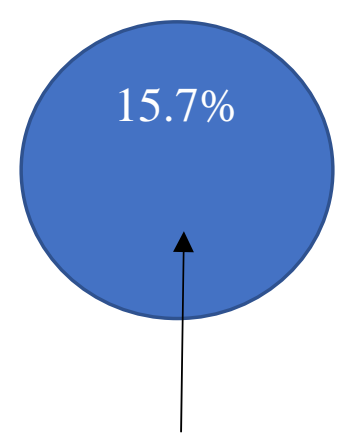

At the hotel (with concierge, etc.)
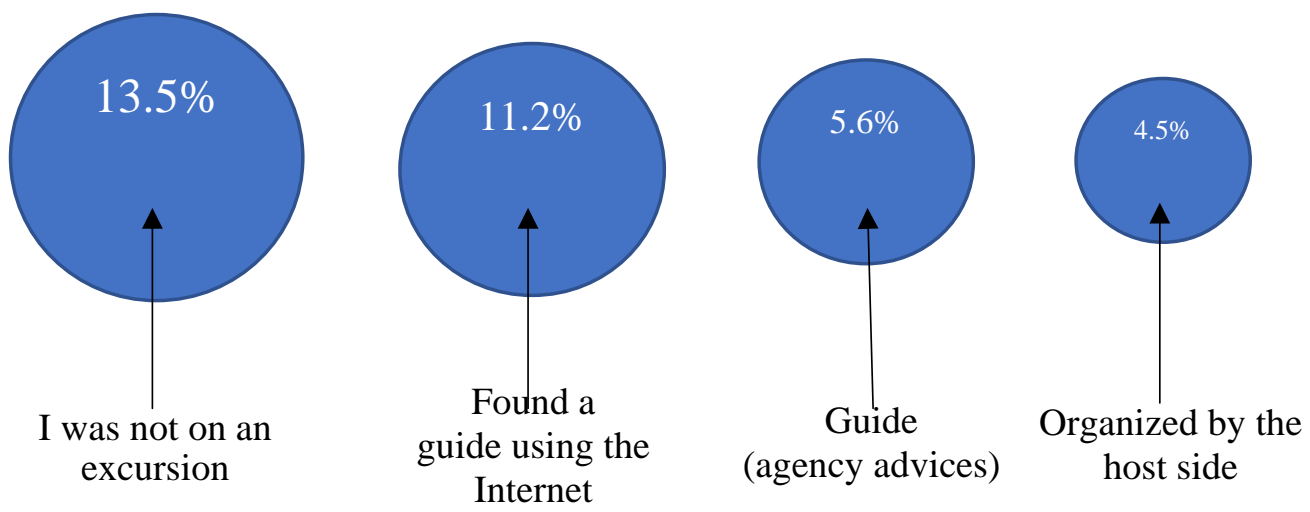

Figure 1.3. Attitude to excursions, (\%)

Source: Tourism by the sea: Statistics of the choice of respondents 2017- 2017

Through this survey, we find out that a third of those surveyed either did not go on excursions or did their own trips. It can also be noted that tourists do not always agree with the recommendations of the tourist enterprise, and do not follow them.

Presenting main material. Excursion is a specific activity that provides information, methodological, organizational, production support services, i.e. excursion service. The basis of such a field is to convey to the consumer certain experiences in order to meet his needs. There is now a problem such as lack of interest in this area. A large number of tourists, respectively consumers, are not interested in excursion service. Why so? Here are the most urgent reasons:

1. Not interesting presentation of the material;

2. Saturation with information;

3. The desire to control the process;

4. Uniformity;

5. High prices.

The representative of the excursion activity should influence the imagination, emotions, subconsciousness, perception using various thematic associations, recreational suggestion. The basis for the excursion is the presence of impressions and stories, and the main active interaction between the guide, object, excursionist. [3] In our time, it is not enough to sell a product, the consumer now needs experience, and this is the basis of the economy of impressions, which affects all components of the tourism sphere. 
Experiences are a distinct economic offering, as distinct from services as services are from goods, but one that - until now - went largely unrecognized. When someone buys a good, he receives a tangible thing; when he buys a service, he purchases a set of intangible activities carried out on his behalf. But when he buys an experience, he pays for a memorable event that a company stages to engage him in an inherently personal way. (Pine, J. And Gilmore, J. (1999) The Experience Economy) [4]

Another pressing issue is the wide choice of the range in the tourism market, which leads to the object of the activity: increased competition; and for the consumer: the complexity of consumer search and choice. The modern consumer makes his choice not only on functions and brand, but on his own feelings and impressions, which he received from the use, there is a need for impression, as in the object of consumption. [5].

An example of an excursion service experience economy:

Previously, there were only museums that offered a passive-overview form of exposure material, but now there are more and more interactive museums where interaction with the exhibition is also possible. For example, the NEMO Museum (Netherlands), the objects in it come to life when are touched, twisted, i.e. played. The main rule is «Necessary to touch!». A learning center where children and adults themselves can experiment and see not only the outcome but also the process. The visitor becomes a participant or manages the process. It does not inspect finished and perfect objects - the results of civilization, as in many other museums, but models natural phenomena and technological processes. [6] The visitor receives the same experience and emotions. In the first place is put not a museum object with its properties and functions, but involved in the scope of the museum.

There are nohigh-level museums with the possibility of interactivity in Ukraine. All of them are at the outdated stage of perception of museum, excursion information. A new approach to understanding the essence of the museum and its public purpose must be developed.

The question is «how to improve the excursion industry?». The solution is to update, to modernizate, to convert. The main aspects of modern museum product offerings, according to Rybakova Y. L. There are the following service components:

- Working schedule (extended working days, absence of days off);

- Development of museum logistics (to reduce queues);

- Use of innovative technologies, updating of material supply;

- Use of modern technologies (electronic maps, audio guides, etc.). [7]

For example, let's take a look at a typical excursion to the National Museum of Arts named after Bohdan and Varvara Hanenko in Kyiv. Wonderful museum, with lots of exhibits and exhibition halls. It is possible to upgrade and not spoil the excursion atmosphere:

1. Attach a QR code plaque next to it, after which the visitor will be able to see a short 40 -second animation depicting the history of the painting, sculpture, etc.; 
2. Create engaging exposures. The presence of interesting exhibits is not enough to attract a sightseeing artist to the spirit of the museum. Create a connection between the world of art and everyday life;

3. Update the tour guide. The usual program is no longer of interest to the modern tourist. If the museum changed the traditional concept, for something more interesting, such as the matic days or each room with its theme, the tourist would get emotions and most likely would return for the magain;

4. To delve deeper into the history of the museum, its architecture, the preservation of the collection and more;

5. Produce an electronic map, with exposure features and the ability to add notes during a tour.

If these steps are followed, the attendance of the museum will increase, the institution will become more unique, modern, in demand, obligatory to visit.

Excursion activities in Ukraine are not enough:

1. Interactivity. Opportunities to be not only an observer but also a participant;

2. Rules: do not negligently perform the same repetitive routine with each visitor;

3. Interactions of the tour guide, the tour guide and the object;

4. But the most important point, you need to create the necessary training program for guides.This will include not only theory but also the study of practical communication. Through this program, employees in this field will learn the right attitude to their profession. The main thing is the explanation of the importance of the economy of impressions, in any economic, servic eactivity.

Conclusion. Modern economy - is an economy of impressions.

The old ways have passed away; you must embrace a new economic reality to be successful and to deserve the trust of those in your care. (B. Joseph Pine II The experience economy) [4].

Excursion activities need serious updating to meet the needs of consumers of our time, because the decisive criterion for choice is the emotions received after consumption. Innovative solutions can serve as a way of reviving cultural life and spiritual development.

\section{REFERENCES}

1. Welcome to the Experience Economy. Retrieved from: Harvard Business Review https://hbr.org/1998/07/welcome-to-the-experience-economy

2. Survey results. Retrieved from: Pikabuhttps://pikabu.ru/story/itogi_oprosa_pro_turizm_ u_morya_5468919

3. M. M. Pokolodna (2017). Organization of excursion activities

4. Pine J. B., Gilmore J. H. (1999). The Experience Economy: Work is Theatre \& Every Business a Stage. Boston: Harvard Business School Press.

5. Osokin V. M. (2014). The concept of impression economy in the development of tourism and hospitality.

6. Petrova D. A. (2012). The role of the museum in modern tourist activity.

7. Rybakova Y. L. (2011). Museums as an object of tourist interest. 